\title{
THE IMMUNOBIOLOGICAL ASSESSMENT OF THE ANTIBODY TITRE IN TREATING CANDIDIASES BY ANTIGENS OF C. ALBICANS FUNGI
}

\author{
M.V.Rybalkin, N.I.Filimonova, O.P.Strilets, L.S.Strelnikov
}

National University of Pharmacy

Key words: candidiasis; antigen; vaccine; immunity; therapy; antibody titre

\begin{abstract}
Every year candidal infections affect a great number of the population, and annually the number of patients is growing around the world. At the premises of the National University of Pharmacy the authors have developed the method of cell disintegration of Candida albicans fungi. For this purpose ultrasonic disintegration at the wavelength of $22 \mathrm{kHz}$ and exposure of $15 \mathrm{~min}$ was used. Then there was filtration through a «Vladipore» membrane MFA-MA No.3 providing separation of the biological material with the size of $10 \mathrm{kDa}$. The aim of our work was the immunobiological assessment of the antibody titres in treating candidiases with the cell-associated antigens of C. albicans fungi. The immunological action of the cell-associated antigens of $C$. albicans fungi in treating candidiases was determined in mice. The mice were preliminary infected with the candidal infection. In 5 days after infection the cell-associated antigens of C. albicans fungi under research with the protein concentration of $3 \mathrm{mg} / \mathrm{ml}$ in the volume of $0.2 \mathrm{ml}$ were injected intramuscularly to mice twice with an interval of 14 days. Nothing was given to the animals of the control group. In 14 days the protective functions of the animals' body were determined by the titres of the specific antibodies of $C$. albicans using enzyme-linked immunoassay (ELISA). When determining the antibody titre after the second injection of the cell-associated antigens of C. albicans fungi it has been found that the antibody titre is in the range of 1:1600 - 4000. The antibody titre in animals of the control group was within 1:400 - 1:1000. Based on the data obtained it may be concluded that the antigens studied have shown the pronounced immunological properties in the experiment in animals.
\end{abstract}

$\mathrm{M}$ odern pharmacy and medicine require creation of a vaccine against candidiasis. This disease constantly affects a great number of the population, and every year the number of patients is growing. The incidence rate of candidiases is associated with irrational use of medicines affecting the immunity and distribution of concomitant diseases suppressing the immune system [1]. The market potential of therapeutic vaccines for treating candidiasis is constantly growing $[3,7]$. So, for example, a vaccine against recurrent candidiasis is specified as the vaccine that improves the quality of life $[3,5]$. And vulvovaginal candidiasis, of course, is not the disease that is life threatening, but can have a devastating impact on the quality of life of many women in the world [5]. A vaccine for treating candidiasis should primarily be designed as a tool for prevention or therapy of candidal infections in patients with a weakened immune system since they have extremely high morbidity and mortality [1].

To fight candidal infections the studies are carried out actively in recent years both on the territory of the former Soviet Union, and in Europe and America [3-8]. At present there are some variants of various vaccines being tested in preclinical and clinical trials in the USA [3]. It should be noted that currently no domestic vaccine is produced in Ukraine and no imported vaccines for prevention and treatment of candidiases have been registered. Therefore, development of a vaccine against candidal infection is the topical issue of modern medicine and pharmacy.

At the premises of the National University of Pharmacy at the Biotechnology Department and the Department of Microbiology, Virology and Immunology the authors have developed the method of cell disintegration of Candida albicans fungi using the ultrasonic cell disrupter at the wavelength of $22 \mathrm{kHz}$ and exposure of $15 \mathrm{~min}$. The use of subunits of cells is a promising direction in developing vaccines [2]. The solution of fungal cell disintegration obtained was filtered through a "Vladipore" membrane MFA-MA No.3 providing separation of the biological material with the size of $10 \mathrm{kDa}$ and its concentration. Then prefiltration using filters with the pore diameter of $0.45 \mu \mathrm{m}$ and sterilizing filtration using filters with the pore diameter of $0.22 \mu \mathrm{m}$ were carried out. Proteins and polysaccharides possessing the antigenic properties are in the composition of the cell extract of Candida fungi. According to the requirements of the SPhU determination of the active substance in such case is conducted by protein. In our previous research the efficiency of the cell-associated antigens of $C$. albicans fungi with the protein concentration of $3 \mathrm{mg} / \mathrm{ml}$ in preventing candidal infection was determined.

The aim of this work is the immunobiological assessment of the cell-associated antigens of Candida albicans fungi in treating candidiases. 
Table

\section{The antibody titres in treating candidiases with the antigens of $C$. albicans fungi}

\begin{tabular}{|c|c|c|c|c|}
\hline \multirow{2}{*}{ Mice } & \multicolumn{4}{|c|}{$\begin{array}{c}\text { The antibody titres of antigens } \\
\text { of C. albicans fungi in ELISA }\end{array}$} \\
\cline { 2 - 5 } & \multicolumn{3}{|c|}{ before injection } & \multicolumn{2}{c|}{ after the second injection } \\
\cline { 2 - 5 } & experiment & control & experiment & control \\
\hline 1 & $1: 200$ & $1: 500$ & $1: 1600$ & $1: 1000$ \\
\hline 2 & $1: 500$ & $1: 400$ & $1: 4000$ & $1: 800$ \\
\hline 3 & $1: 400$ & $1: 200$ & $1: 3200$ & $1: 400$ \\
\hline 4 & $1: 400$ & $1: 400$ & $1: 3200$ & $1: 800$ \\
\hline 5 & $1: 300$ & $1: 200$ & $1: 2400$ & $1: 400$ \\
\hline 6 & $1: 300$ & $1: 400$ & $1: 2400$ & $1: 800$ \\
\hline $\begin{array}{c}\text { Median and its } \\
\text { confidence interval }\end{array}$ & $1: 350 \pm 98$ & $1: 440 \pm 103$ & $1: 2800 \pm 795$ & $1: 800 \pm 182$ \\
\hline
\end{tabular}

Note: experiment - the cell-associated antigens of $C$. albicans fungi with the protein concentration of $3 \mathrm{mg} / \mathrm{ml}$, control - intact animals.

\section{Materials and Methods}

The immunological action of the cell-associated antigens of C. albicans fungi in treating candidiases was determined in the experiments with healthy two month white mice weighing 18-22 g. There were six animals in the control and experimental groups each; they were kept in the same conditions on a standard diet. Before the research the animals acclimatized themselves under experimental room conditions. The mice were preliminary infected with the candidal infection. For this purpose the suspension of $C$. albicans fungi in the amount of $20 \mathrm{mln}$ of cells in the volume of $1 \mathrm{ml}$ was used; the fungi were introduced with an interval of 1 hour. After that the symptoms of the disease indicating development of candidiasis in animals were revealed. These main symptoms were unkempt appearance, refusal to eat, the body weight loss, dysfunctions of the excretory organs, etc. In 5 days after infection the cell-associated antigens of $C$. albicans fungi under research with the protein concentration of $3 \mathrm{mg} / \mathrm{ml}$ in the volume of $0.2 \mathrm{ml}$ were injected intramuscularly to mice in the upper part of the rear right paw. In 14 days the antigens of $C$. albicans fungi with the pro- tein concentration of $3 \mathrm{mg} / \mathrm{ml}$ in the volume of $0.2 \mathrm{ml}$ were injected again in the upper part of the left rear paw. Nothing was given to the animals of the control group. In 14 days the protective functions of the animals' body were determined by the titres of the specific antibodies of $C$. albicans using enzyme-linked immunoassay (ELISA) according to SphU, ed. I, art. 2.7.1, p. 55-57. For this purpose the reagent kit for immunoassay detection of antibodies of class $\mathrm{G}$ was used for $C$. albicans by means of "Vector-Best" ELISA test system produced in Russia.

\section{Results and Discussion}

The results of the research demonstrated that prior the injection the antibody titres of healthy animals were in the range of 1:200 1:500. It can be explained by a possible contact with the fungus of the Candida genus in the process of life activities of mice or a possible carrier state of this type of fungi since they are part of the normal microflora of animals. After double infection of the cell-associated antigens of $C$. albicans fungi with the protein concentration of $3 \mathrm{mg} / \mathrm{ml}$ with an interval of 14 days there is an increase in the antibody titre within the range of 1:600 -
1:4000. The antibody titre in the control group was in the range of 1:400 - 1:1000. To obtain reliable results of the study all the values obtained were statistically processed, the median for all groups and its confidence interval were calculated. The median and the confidence interval of the antibody titre in animals of the control and experimental groups before infection was 1:350 \pm 98 and 1:400 \pm 103 ; after infection and injections it was $1: 2800 \pm 795$ in animals of the experimental group and 1:800 \pm 182 in animals of the control group. Comparing the results obtained in the experimental and control group it is a fair assumption to say that introduction of the cell-associated antigens of Candida albicans stimulates formation of antibodies, which are responsible for the humoral immunity.

In biomedical research there are occasions when comparing individual parameters it is necessary to estimate the significance of the difference between them. A significant difference between the individual indicators of the sampling study suggests the possibility of transferring these findings to the main entity. The confidence factor (Student t-test) is the criterion for assessing the significance of the difference. As a result of the research conducted the confidence coefficients $t=3$ and $t=4$ corresponding to $t>2$ (corresponds to the probability of accurate prediction of $95 \%$ ) were obtained for the experimental and control groups of animals before and after injection. The research results are given in Table.

Based on these data it can therefore be said that the antigens of C. albicans fungi can be potential antigens for development of a vaccine for prevention and treatment of candidal infection.

\section{CONCLUSIONS}

1. The cell-associated antigens of Candida albicans with the protein concentration of $3 \mathrm{mg} / \mathrm{ml}$ in treating candidal infection have been researched. 
2. As a result of the research conducted it has been found that the cell-associated antigens of $C$. albicans fungi provide high titres of antibodies in all animals in double intramuscular introduction in the volume of $0.2 \mathrm{ml}$.

3. The antigens of $C$. albicans fungi with the protein concentration of $3 \mathrm{mg} / \mathrm{ml}$ have been selected for further research; based on them it is planned to develop a vaccine for prevention and treatment of candidal infection.

\section{REFERENCES}

1. Голубка О.В. // Annals of Mechnikov Institute. - 2011. - №2. - C. 51-59.

2. Петров Р.В., Хаитов Р.М. Иммуногены и вакцины нового поколения. - М.: ГЭоСТАР-Медицина, 2011. $-608 \mathrm{c}$.

3. Cassone A., Casadevall A. // Curr. Opin. Microbiol. - 2012. - Vol. 15. - P. 1-7.

4. Carvalho A., Cunha C. // Front. Microbiol. - 2012. - Vol. 3. - P. 1-9.

5. De Bernardis F. et al. // Vaccine. - 2012. - № 30. - P. 4490-4498.

6. Diekema D., Arbefeville S., Boyken L. et al. // Diagn. Microbiol. Infect. Dis. - 2012. - №73. - P. 45-48.

7. Edwards J.E. // Med. Microbiol. - 2012. - №61. - P. 895-903.

8. Han Y., Rhew K.Y. // Arch. Pharm. Res. - 2012. - №35. - P. 2021-2027.

IМУНОБІОЛОГІЧНА ОЦІНКА ТИТРУ АНТИТІЛ ПРИ ТЕРАПІЇ КАНДИДАМІКОЗІВ АНТИГЕНАМИ ГРИБІВ С. ALВICANS

М.В.Рибалкін, Н.І.Філімонова, О.П.Стрілець, Л.С.Стрельников

Національний фармацевтичний університет

Ключові слова: кандидамікоз; антиген; вакцина; імунітет; терапія; титр антитіл

3 кожним роком кандидозна інфекція охоплює все більшу і більшу кількість людей по всьому світу. Авторами на базі Національного фармацевтичного університету був розроблений метод дезінтеграції клітин грибів C. аlbicans. Для цього використовували ультразвукову дезінтеграцію при довжині хвилі 22 кГц та експозиції 15 хв. Далі проводили фільтрацію через мембрану «Владіпор» МФА-МА №3, яка забезпечує відсікання матеріалу з розміром 10 кДа. Завданням нашої роботи стала імунобіологічна оцінка титрів антитіл при терапї кандидамікозом антигенами клітин грибів C. albicans. Визначення імунологічної дї отриманих антигенів клітин грибів C. аlbісапs при терапії кандидамікозів проводили на мишах. Попередньо мишей заражали кандидозною інфекцією. Через 5 днів після зараження мишам внутрішньом'язово вводили дворазово з інтервалом 14 діб по 0,2 мл досліджуваних антигенів C. albicans з концентрацією білка 3 мг/мл. Тваринам у контрольній групі нічого не вводили. Через 14 діб проводили визначення захисних функцій організму тварин по титрах специфічних антитіл C. albicans при проведенні імуноферментного аналізу. При визначенні титру антитіл після другої ін'єкції антигенів клітин грибів C. albicans встановлено, що титр антитіл знаходиться в діапазоні 1:1600-4000. У тварин контрольної групи титр антитіл становив 1:400-1:1000. Грунтуючись на отриманих результатах, можна зробити висновок, що досліджувані антигени проявили виразні імунобіологічні властивості в експерименті на тваринах.

\section{ИММУНОБИОЛОГИЧЕСКАЯ ОЦЕНКА ТИТРОВ АНТИТЕЛ ПРИ ТЕРАПИИ КАНДИДАМИКОЗОВ АНТИГЕНАМИ ГРИБОВ С. ALBICANS}

Н.В.Рыбалкин, Н.И.Филимонова, О.П.Стрилец, Л.С.Стрельников

Национальный фармацевтический университет

Ключевые слова: кандидамикоз; антиген; вакцина; иммунитет; терапия; титр антител

С каждым годом кандидозная инфекция охватывает все большее и большее количество людей по всему миру. Авторами на базе Национального фармацевтического университета был разработан метод дезинтеграции клеток грибов C. albicans. Для этого использовали ультразвуковую дезинтеграцию при длине волны 22 кГц и экспозиции 15 мин. Далее проводили фильтрацию через мембрану «Владипор» МФА-МА №3, которая обеспечивает отсечение материала с размером 10 кДа. Задачей нашей работы стала иммунобиологическая оценка титров антител при терапии кандидамикозов антигенами клеток грибов C. albicans. Определение иммунологического действия полученных антигенов клеток грибов C. albicans при терапии кандидамикозов проводили на мышах. Предварительно мышей заражали кандидозной инфекцией. Через 5 дней после заражения мышам внутримышечно вводили двукратно с интервалом 14 суток 0,2 мл исследуемых антигенов C. albicans с концентрацией белка 3 мг/мл. Животным в контрольной группе ничего не вводили. Через 14 суток проводили определение защитных функций организма животных по титрам специфических антител C. albicans при проведении иммуноферментного анализа. При определении титра антител после второй инъекции антигенов клеток грибов C. albicans установлено, что титр антител находится в диапазоне 1:1600-4000. У животных контрольной группы титр антител составлял 1:400-1:1000. Основываясь на полученных результатах, можно сделать вывод, что исследуемые антигены проявили выраженные иммунологические свойства в эксперименте на животных. 